\title{
Occupational Hazards and Safety in Railways Maintenance
}

\author{
Fadia Ahmed El-Marakby*
}

\begin{abstract}
Occupational hazards typically associated with locomotive and railcar maintenance activities may include physical, chemical, and biological hazards as well as confined space entry hazards. The aim of the present study is to assess the occupational hazards among workers involved in locomotive and railcar maintenance activities and to evaluate Occupational health and safety performance. Physical and chemical hazards are evaluated. On comparing with TLVs. Workers in welding and wood working are exposed to noise of (78.4-102.0) $\mathrm{dB}(\mathrm{A})$ with the mean of $90.96 \pm 10.6$, and $(84.0-100.0) \mathrm{dB}(\mathrm{A})$ with the mean of $90.98 \pm 6.7$, respectively. Although workers in wood working are exposed to insufficient lighting in the range of (100-190) lux with the mean of $140 \pm$ 35.4 , workers in thermal station and compressors station are exposed to defective lighting in the range of (60-360) lux with the mean of $164 \pm 121.2$ and (70-520) lux with the mean of $248 \pm 176.8$ due to improper light distribution as lighting was only adequate near gates. Exposures to chemical hazards are below the limits except for acid mists in batteries recharging process; this may be due to the limitation of the area in spite of the fact that the area is opened. Other hazards may include the potential for fire and explosion during the conduct of hot work in storage tank systems. Confined spaces may include access to railroad tank and cars during repair and maintenance. The need for improvement of occupational safety and health standards in the unorganized sector assumes very high priority. It is required to provide machinery and equipment which are safe and also to maintain guards in position and working order while a machine or equipment is in use. Specific requirements relating to protective equipment for eyes, for workers entering confined spaces or working at heights have been made. In terms of the administration of the OSH legislations, there has been a lack of educational and awareness effort. The general approach has been to make legislation and expect compliance while the need is for a proactive approach to reach out the persons responsible for compliance through well designed educational/awareness campaigns. Railway maintenance is considered one of the unorganized sectors in Egypt. Data base and health education are recommended.
\end{abstract}

\section{INTRODUCTION}

Typical railway components include

locomotives and railroad cars, known as

rolling stocks, in addition to fixed repair facilities. ${ }^{[1]}$

Maintenance activities may consist of routine servicing or heavy mechanical infrastructure, includes tracks, stations, maintenance activities. Routine infrastructure, includes tracks, stations, maintenance activities. Routine fueling facilities, and maintenance and maintenance activities may include * Occupational Health and Air Pollution Department. High Institute of Public Health. Alexandria University 
lubricating oil changes and mechanical tools, and electrical safety issues. safety inspections, exterior washing of Chemical hazards may include potential locomotives and wagons, and interior exposure to a variety of hazardous washing of rail tankers. Heavy mechanical materials (e.g., asbestos, PCB, toxic paint, maintenance may include replacement of heavy metals, and VOCs including those rolling and engine components, engine resulting from the use of solvent-based overhauls, mechanical tests, and paint and cleaning solvents in enclosed adjustments. It may also include parts machining, welding, cleaning (including degreasing), and other types of activities typically conducted in metal machines shops. Passenger and cargo wagons may also be cleaned and painted, including touch up painting, during heavy maintenance. [2]

Occupational hazards typically associated with locomotive and railcar maintenance activities may include physical, chemical, and biological hazards as well as confined space entry hazards. Physical hazards may be associated with work in proximity to moving equipment (e.g., locomotive and other vehicles) and machine safety including work portable space. Other chemical hazards may include the potential for fire and explosion during the contact of hot work in storage tank systems. Biological hazards may include potential exposures to pathogens present in sewage storage compartments. Confined spaces may include access to railroad tank and grain car during repair and maintenance. [3]

Occupational health and safety performance should be evaluated against internationally published exposure guidelines. Projects should try to reduce the accidents among project workers to a rate of zero, especially accidents that could result in a loss work time, different levels of disability, or even fatality. ${ }^{[4]}$ 
The aims of the present study are:

1- To assess the occupational hazards among workers involved in locomotive and railcar maintenance activities.

2- To evaluate Occupational health and safety performance.

\section{MATERIAL AND METHODS}

\section{1-Material}

There are three governmental workshops in Alexandria that carry out routine maintenance activities, two of them are in Kabaari zone and the third one is in El-Hadara zone. The pattern of work in the three workshops is identical.

\section{2- Methods}

\section{A-Physical hazards}

The main physical hazards to be evaluated are noise, illumination, and heat stress. Noise is considered the main physical hazard. It was measured in different departments and operations in the selected facilities using sound level meter calibrated at $114 \mathrm{~dB}{ }^{[5]}$ Illumination was measured using Lux meter. ${ }^{[6]}$ Heat stress was measured as WBGT index using WBGT-Heat stress monitor. ${ }^{[7]}$

\section{B-Chemical hazards}

Particulates were collected using cellulose membrane filters fitted to a portable personal pump of about $2 \mathrm{~L} / \mathrm{min}$ flow rate. ${ }^{[8]}$

VOCs were evaluated using Teflon tubes of about $10 \mathrm{~cm}$ long filled with charcoal of known weight fitted to portable personal pump of about $0.12 \mathrm{~L} / \mathrm{min}$ flow rate. ${ }^{[9]}$

Nitrogen oxides (NOx) and sulphur dioxide $\left(\mathrm{SO}_{2}\right)$ were determined by Griess- Saltzman reaction using $20 \mathrm{ml}$ of $0.1 \% \quad \mathrm{~N}$-(1-naphthyl)-ethylene diamine dihydrochloride as trapping medium for NOx ${ }^{[10]}$ and colorimetrically using $20 \mathrm{ml}$ of $0.04 \mathrm{M}$ potassium tetrachoromercurate as trapping medium for $\mathrm{SO}_{2}{ }^{[11]}$, respectively. Carbon monoxide (CO) was determined by using direct reading $\mathrm{CO}$-analyser. [12]

Occupational health and safety were be evaluated against internationally published 
exposure guidelines, of which examples include the Threshold Limit Value (TLV®) occupational exposure guidelines published by American Conference of Governmental Industrial Hygienists (ACGIH). [13]

\section{RESULTS AND DISCUSSION}

At present, comprehensive safety and health statutes for regulating safety and health of persons at work exists only in respect of factories. In addition, there is a need for regulating safety in particular activities, operations, sectors such as transport, storage and handling of explosives, petroleum, insecticides, radioactive materials, installations, use and maintenance of boilers and unfired pressure vessels and operations of Railways, Shipping and Aviation. Thus, the approach is to lay down specific and detailed requirements to prevent risk of injuries in specific operations or circumstances. This approach lacks uniformity and well-coordinated approach to safety and health in all sectors of the economy.

\section{A-Physical hazards}

Table (1) shows the physical hazards in different maintenance operations including: Smithery, Wax removal, Welding, Turnery, Wood working, Batteries, as well as thermal and compressors stations. On comparing with TLVs, the exposure range has slightly exceeded the TLVs among workers in smithery and welding who are exposed to heat stress of (23.4-27.5) ${ }^{\circ} \mathrm{C}$ with the mean of $25.58 \pm 1.5$ and $(22.2-27.5){ }^{\circ} \mathrm{C}$, with the mean of $25.24 \pm 2.1$, respectively (TLVs = $29.4^{\circ} \mathrm{C}$ ). As measurements were taken in spring, it is expected that the values may be higher in summer.

Workers in welding and wood working are exposed to noise of (78.4102.0) $d B(A)$ with the mean of $90.96 \pm$ 10.6, and (84.0-100.0) dB (A) with the mean of $90.98 \pm 6.7$, respectively [TLVs $=$ $90 \mathrm{~dB}(\mathrm{~A})]$. The upper limits of exposure 
ranges were due to using of equipment and tools in these departments.

Although workers in wood working are exposed to insufficient lighting in the range of (100-190) lux with the mean of $140 \pm 35.4$, workers in thermal station and compressors station are exposed to defective lighting in the range of (60-360) lux with the mean of $164 \pm 121.2$ and (70520) lux with the mean of $248 \pm 176.8$ due to improper light distribution as lighting was only adequate near gates (permissible level = 215 lux). Otherwise, it is clear from the proceeding results that heat stress, noise, and level of illumination were within the permissible limits,

\section{B-Chemical hazards}

Table (2) shows the chemical hazards in different maintenance operations including: Smithery, Wax removal, Welding, Turnery, Wood working, and Batteries. Workers are exposed to nitrogen oxides $(3.32 \pm 0.08)$, sulfur dioxide (2.35 \pm 1.25$)$, carbon monoxide $(0.67 \pm 0.58)$, and particulates $(4.69 \pm 0.99)$ in smithery in the safe level below the TLVs of $5,6,55$, and $10 \mathrm{mg} / \mathrm{m}^{3}$, respectively. Workers in wax removal are exposed to hydrocarbons of $372.65 \pm 10.77 \mathrm{mg} / \mathrm{m} 3$ in the safe level below the TLVs $\left(500 \mathrm{mg} / \mathrm{m}^{3}\right)$._ Workers are exposed to nitrogen oxides $(4.43 \pm 0.40)$, sulfur dioxide (3.28 \pm 0.38$)$, and particulates $(5.16 \pm 0.04)$ in welding in the safe level below the $\operatorname{TLVs}\left(5,6\right.$, and $10 \mathrm{mg} / \mathrm{m}^{3}$, respectively. Workers in turnery and woodworking are exposed to particulates of $(5.18 \pm 1.79)$ and $(4.80 \pm 0.62)$, respectively in the safe level below $10 \mathrm{mg} / \mathrm{m}^{3}$. Workers are exposed to acid mist in batteries recharging process of $(2.14 \pm 0.96)$ in comparable to TLV of $1 \mathrm{mg} / \mathrm{m}^{3}$.

Exposures to chemical hazards are below the limits except for acid mists in batteries recharging process; this may be due to the limitation of the area in spite of the fact that the area is opened. 
Other hazards may include the maintain guards in position and working potential for fire and explosion during the order while a machine or equipment is in conduct of hot work in storage tank use. Specific requirements relating to systems. Confined spaces may include access to railroad tank and cars during repair and maintenance. All of these occupational health and safety hazards should be managed based on the recommendations provided in the general OHS guidelines.

The need for improvement of occupational safety and health standards in some unorganized sectors assumes very high priority in today's social environment. Ministry of Labor being the apex body in the country with a mandate of alleviation of working conditions for the large sector not covered so far envisage that the new plan schemes proposed would go a long way in achieving of the goal of safe and healthy workplace for the whole of labor force of the country. $\left.{ }^{[14}\right]$

It is required to provide machinery and equipment which are safe and also to protective equipment for eyes, for workers entering confined spaces or working at heights have been made. Special equipment such as hoists, lifts, cranes, and other lifting appliances, pressure vessels, and exhaust equipment are required to be tested and periodically examined and certified by competent persons. Precautions for preventing fire and explosions and escape in case such events take place are provided. The Inspectors have been empowered to stop any work where danger to the life or limbs or health of workers is imminent. ${ }^{[15]}$

In terms of the administration of the $\mathrm{OSH}$ legislations; there has been a lack of educational and awareness effort. The general approach has been to make legislation and expect compliance; while the need is for a proactive approach to reach out the persons responsible for 
compliance through well designed educational/awareness campaigns such as the targeted conferences, seminars, literature in the form of simple leaflets, and media participation. ${ }^{[16]}$

\section{CONCLUSION AND RECOMMENDATIONS}

Railway maintenance is considered one of the unorganized sectors in Egypt.

\section{Recommendations}

1- Data-base: Shortage of data is always an obstacle in organizing, developing, and supplying of occupational health and safety services. As regards railways workers, the scheme of work is not definite and also the number of working hours as they depend on the actual work required. So that, we are badly in need of establishing data base of different occupational exposures and their adverse health effects on railways workers.

2- Health education: As railway maintenance includes diversity of processes and uses diversity of equipment and tools, health education programs should be directed to manage workers safe acts and behaviors.

3- Control of hazards and stress factors: Efforts should be directed to control of hazards such as applying local exhaust ventilation for acid mist and particulates, maintenance of tools and equipment and applying ear protection for noise. Also, regulations should be stricted towards the number of work hours. 
Table (1): Physical hazards in different maintenance processes

\begin{tabular}{|c|c|c|c|}
\hline Process & $\begin{array}{l}\text { Heat stress } \\
\left.\text { (WBGT: }{ }^{\circ} \mathrm{C}\right)\end{array}$ & $\begin{array}{c}\text { Noise } \\
\text { (Decibel) }\end{array}$ & Level of Illumination (Lux) \\
\hline $\begin{array}{l}\text { Smithery } \\
\text { Range } \\
\text { Mean } \pm \text { S.D. }\end{array}$ & $\begin{array}{c}(23.4-27.5) \\
25.58 \pm 1.5\end{array}$ & $\begin{array}{c}(88.4-93.2) \\
89.78 \pm 2.4\end{array}$ & $\begin{array}{c}(225-390) \\
321 \pm 70.4\end{array}$ \\
\hline$p$ & $<0.05^{\star}$ & $>0.05$ & $<0.001^{*}$ \\
\hline $\begin{array}{c}\text { Wax removal } \\
\text { Range } \\
\text { Mean } \pm \text { S.D. }\end{array}$ & $\begin{array}{c}(19.2-24.0) \\
21.6 \pm 1.8\end{array}$ & $\begin{array}{c}(79.3-83.9) \\
81.28 \pm 1.8\end{array}$ & $\begin{array}{c}(280-400) \\
338 \pm 51.7\end{array}$ \\
\hline$p$ & $<0.05^{\star}$ & $<0.05^{\star}$ & $<0.001^{\star}$ \\
\hline $\begin{array}{l}\text { Welding } \\
\text { Range } \\
\text { Mean } \pm \text { S.D. }\end{array}$ & $\begin{array}{c}(22.5-27.5) \\
25.24 \pm 2.1\end{array}$ & $\begin{array}{c}(78.4-102.0) \\
90.96 \pm 10.6\end{array}$ & $\begin{array}{c}(220-400) \\
324 \pm 82.6\end{array}$ \\
\hline $\mathbf{p}$ & $<0.05^{\star}$ & $>0.05$ & $<0.001^{\star}$ \\
\hline $\begin{array}{l}\text { Turnery } \\
\text { Range } \\
\text { Mean } \pm \text { S.D. }\end{array}$ & $\begin{array}{c}(20.0-22.5) \\
21.3 \pm 1.0\end{array}$ & $\begin{array}{c}(82.5-92.2) \\
86.08 \pm 3.7\end{array}$ & $\begin{array}{c}(200-300) \\
246 \pm 39.7\end{array}$ \\
\hline $\mathbf{p}$ & $<0.05^{\star}$ & $<0.05^{\star}$ & $<0.01^{*}$ \\
\hline $\begin{array}{l}\text { Wood working } \\
\text { Range } \\
\text { Mean } \pm \text { S.D. }\end{array}$ & $\begin{array}{c}(19.0-20.0) \\
19.48 \pm 0.4\end{array}$ & $\begin{array}{c}(84.0-100.0) \\
90.98 \pm 6.7\end{array}$ & $\begin{array}{c}(100-190) \\
140 \pm 35.4\end{array}$ \\
\hline $\mathbf{P}$ & $<0.05^{\star}$ & $>0.05$ & $<0.001^{*}$ \\
\hline $\begin{array}{l}\text { Thermal station } \\
\text { (Boilers) } \\
\text { Range } \\
\text { Mean } \pm \text { S.D. } \\
\end{array}$ & $\begin{array}{c}(19.1-19.7) \\
19.32 \pm 0.2\end{array}$ & $\begin{array}{c}(86.0-88.0) \\
87.04 \pm 0.8\end{array}$ & $\begin{array}{l}(60-360) \\
164 \pm 121.2\end{array}$ \\
\hline $\mathbf{P}$ & $<0.05^{\star}$ & $<0.05^{\star}$ & $<0.01^{*}$ \\
\hline $\begin{array}{l}\text { Batteries } \\
\text { Range } \\
\text { Mean } \pm \text { S.D. }\end{array}$ & $\begin{array}{c}(20.0-24.0) \\
21.9 \pm 1.6\end{array}$ & $\begin{array}{c}(62.0-70.0) \\
66.6 \pm 3.2\end{array}$ & $\begin{array}{c}(270-300) \\
283 \pm 12.0\end{array}$ \\
\hline $\mathbf{P}$ & $<0.05^{\star}$ & $<0.001^{*}$ & $<0.01^{*}$ \\
\hline $\begin{array}{l}\text { Compressors } \\
\text { station } \\
\text { Range } \\
\text { Mean } \pm \text { S.D. }\end{array}$ & $\begin{array}{c}(19.5-23.5) \\
21.5 \pm 1.6\end{array}$ & $\begin{array}{c}(60.9--80.9) \\
69.58 \pm 8.0\end{array}$ & $\begin{array}{l}(70-520) \\
248 \pm 176.8\end{array}$ \\
\hline & $<0.05^{\star}$ & $<0.001^{\star}$ & $<0.01^{*}$ \\
\hline Permissible limits & 29.4 & 90.0 & 215 \\
\hline
\end{tabular}

$-n=5$ 
Table (2): Chemical hazards in different maintenance processes

\begin{tabular}{|l|c|c|c|c|c|}
\hline Process & \multirow{2}{*}{$\begin{array}{c}\text { Chemical } \\
\text { hazards }\end{array}$} & \multicolumn{2}{|c|}{ Concentration } & TLVs & P \\
\cline { 3 - 4 } & & Range & Mean \pm S.D. & & \\
\hline Smithery & Nitrogen oxides & $(3.25-3.40)$ & $3.32 \pm 0.08$ & 5.00 & $<0.01^{\star}$ \\
& $\begin{array}{c}\text { Sulfur dioxide } \\
\text { Carbon }\end{array}$ & $(0.91-3.18)$ & $2.35 \pm 1.25$ & 6.00 & $<0.01^{\star}$ \\
& monoxide & $(0.00-1.15)$ & $0.67 \pm 0.58$ & 55.00 & $<0.001^{\star}$ \\
& Particulates & $(3.54-5.32)$ & $4.69 \pm 0.99$ & 10.00 & $<0.05^{\star}$ \\
\hline Wax removal & Hydrocarbons & $(363.35-384.45)$ & $372.65 \pm 10.77$ & 500.00 & $<0.05^{\star}$ \\
\hline Welding & Nitrogen oxides & $(4.00-4.80)$ & $4.43 \pm 0.40$ & 5.00 & $>0.05 N . S$ \\
& Sulfur dioxide & $(2.97-3.70)$ & $3.28 \pm 0.38$ & 6.00 & $<0.05^{\star}$ \\
& Particulates & $(5.12-5.20)$ & $5.16 \pm 0.04$ & 10.00 & $<0.05^{\star}$ \\
\hline Turnery & Particulates & $(3.33-6.90)$ & $5.18 \pm 1.79$ & 10.00 & $<0.01^{\star}$ \\
\hline Wood working & Particulates & $(4.10-5.30)$ & $4.80 \pm 0.62$ & 10.00 & $<0.01^{*}$ \\
\hline Batteries & Acid mist & $(1.11-3.00)$ & $2.14 \pm 0.96$ & 1.00 & $<0.05^{\star}$ \\
\hline
\end{tabular}

$\mathrm{n}=3$

Values are expressed as $\mathrm{mg} / \mathrm{m}^{3}$

\section{REFERENCES}

1- IFC: International Finance Corporation. Environmental, health, and safety guidelines for railways. April 30, 2007.pp 1-19

2- EEA: European Environment Agency, Spatial and ecological assessment of the ten - demonstration of indicators and GIS methods, 1998. Cited in ref. (1)

3- Association of American Railways, Manual of standards and recommended practices. Section $\mathrm{M}-$ Locomotives and locomotive interchange equipment. 2002. Cited in ref. (1)

4- Barkan, Christopher P L, Dick C, Tyler, Anderson R . 2003. Analysis of railroad derailment factors affecting hazardous materials transportation risk. Transportation research record 1825: $48-55$.

5- Rabinowitz PM. Noise-induced hearing loss. Am Fam Physician. 2000; 61(9): 2749-60.
6- Vihma T, Nurminer M. Illumination in Small Industry. Am Ind Hyg Assoc J. 1983; 44(7):501-4.

7- Botsfad J.H. A wet Globe Thermometer for Environmental Heat Measurement. Am Ind Hyg Assoc J. 1971; 32:1- 10

8- Robert BW. Personal respirable mass sampling procedure - Report. US Public Health Services R.R.-7. Cincinnati, Ohio, 45202, 1968.

9- ASTM. Designation, standard practice for selection of sorbents, and pumped sampling thermal adsorption analysis procedures for volatile organic compounds in air D 6196 - 97, USA, 1997.

10- Morris K. Methods of air sampling and analysis. USA: APHA: American Public Health Association; 2003. p.329

11- ibid. p. 447

12- ibid. p. 230

13- ACGIH: American conference of governmental industrial hygienists, threshold limit values and biological 
exposure indices 2000/2001, Cincinnati, Ohio: ACGIH; 2007

14- Report of the working group on $\mathrm{OSH}$ for the tenth five year plan (20022007). Government of India. Serial number 47/2001.Sept.2001. pp159

15- CCOHS: Canadian Centre for Occupational Health and Safety. Loading and unloading vehicles. Last updated Oct. 13, 2006. Available from: www.ccohs.ca.html. Retrieved at Nov.5, 2008.

16- ORR: Office of Railway Regulation. Railway Safety (Miscellaneous Provisions) Regulations 1997. Evaluation and consultation on next steps. April 2008.p1-25. 


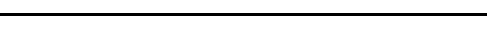

